\title{
A soil moisture monitoring network to characterize karstic recharge and evapotranspiration at five representative sites across the globe
}

\author{
Romane Berthelin ${ }^{1}$, Michael Rinderer ${ }^{2}$, Bartolomé Andreo $^{3}$, Andy Baker $^{4}$, Daniela Kilian $^{5}$, Gabriele Leonhardt $^{5}$, \\ Annette Lotz ${ }^{5}$, Kurt Lichtenwoehrer ${ }^{5}$, Matías Mudarra ${ }^{3}$, Ingrid Y. Padilla ${ }^{6}$, Fernando Pantoja Agreda ${ }^{6}$, \\ Rafael Rosolem ${ }^{7}$, Abel Vale ${ }^{8}$, and Andreas Hartmann ${ }^{1,7}$ \\ ${ }^{1}$ Chair of Hydrological Modeling and Water Resources, University of Freiburg, Freiburg 79098, Germany \\ ${ }^{2}$ Chair of Hydrology, University of Freiburg, Freiburg 79098, Germany \\ ${ }^{3}$ Department of Geology and Centre of Hydrogeology, University of Malaga, Málaga, 29071, Spain \\ ${ }^{4}$ Connected Waters Initiative Research Centre, UNSW, Sydney, NSW 2052, Australia \\ ${ }^{5}$ Research Department, Nationalpark Berchtesgaden, Berchtesgaden 83471, Germany \\ ${ }^{6}$ Department of Civil Engineering and Surveying, University of Puerto Rico, Mayagüez, 00682, Puerto Rico \\ ${ }^{7}$ Department of Civil Engineering, University of Bristol, Bristol, BS8 1TR, UK \\ ${ }^{8}$ Ciudadanos del Karso, 267 Sierra Morena PMB 230, San Juan, 009264, Puerto Rico
}

Correspondence: Romane Berthelin (romane.berthelin@hydmod.uni-freiburg.de)

Received: 8 July 2019 - Discussion started: 1 August 2019

Revised: 19 December 2019 - Accepted: 14 January 2020 - Published: 25 February 2020

\begin{abstract}
Karst systems are characterized by a high subsurface heterogeneity, and their complex recharge processes are difficult to characterize. Experimental methods to study karst systems mostly focus on analysing the entire aquifer. Despite their important role in recharge processes, the soil and epikarst receive limited attention, and the few available studies were performed at sites of similar latitudes. In this paper, we describe a new monitoring network that allows for the improvement of the understanding of soil and epikarst processes by including different karst systems with different land-cover types in different climate regions. Here, we present preliminary data form the network and elaborate on their potential to answer research questions about the role of soil and epikarst on karstic water flow and storage. The network measures soil moisture at multiple points and depths to understand the partitioning of rainfall into infiltration, evapotranspiration, and groundwater recharge processes. We installed soil moisture probes at five different climate regions: Puerto Rico (tropical), Spain (Mediterranean), the United Kingdom (humid oceanic), Germany (humid mountainous), and Australia (dry semi-arid). At each of the five sites, we defined two $20 \mathrm{~m} \times 20 \mathrm{~m}$ plots with different land-use types (forest and grassland). At each plot, 15 soil moisture profiles were randomly selected and probes at different depths from
\end{abstract}

the topsoil to the epikarst (in total over 400 soil moisture probes) were installed. Covering the spatio-temporal variability of flow processes through a large number of profiles, our monitoring network will allow researchers to develop a new conceptual understanding of evapotranspiration and groundwater recharge processes in karst regions across different climate regions and land-use types, and this will provide the base for quantitative assessment with physically based modelling approaches in the future.

\section{Introduction}

Around a quarter of the global population fully or partially depends on water from karst aquifers (Ford and Williams, 2007). In times of climate change, land-use changes, and growing population, this water availability is more and more vulnerable both in terms of water quantity and quality (Wada et al., 2010; Vörösmarty et al., 2010). Karst aquifers form through the chemical dissolution of carbonate rocks. This process, called karstification, leads to subsurface heterogeneity expressed by features like conduits, caves, sinkholes, and dolines (Hartmann et al., 2014). These geomorphologic heterogeneities lead to variable pathways and velocities that 
are highly variable in space and time. For that reason, karst aquifers have always posed a challenge in the characterization of hydrological processes for quantification of their present and future water storages (Goldscheider and Drew, 2007).

Various experimental methods have been used in order to characterize karst systems. The most popular among them is the application of methods to analyse signals of artificial and natural tracers at karst springs (see review in Hartmann et al., 2014; Goldscheider and Drew, 2007). Artificial tracers have been used to investigate the actual flow paths and flow times through karst systems (Mudarra et al., 2014; Goldscheider et al., 2008), while natural tracers, e.g. water isotopes, were used to understand the transit times and dispersion of water entering at the entire recharge of karst systems (Maloszewski et al., 2002). Continuous monitoring of karst spring hydrographs and the hydrochemical signal have shown to reveal important information about the subsurface structure and dynamics of karst aquifers (Mudarra and Andreo, 2011). Hydraulic methods like pumping tests revealed the local heterogeneity of hydraulic conductivities of karst aquifers (Giese et al., 2018), and geophysical methods allowed for the collection of information about geometrical characteristics of the aquifer (Chalikakis et al., 2011) and thus the degree of development of the epikarst. Finally, information from measurements in the field can be used in models. Using rainfall data as input, Mazzilli et al. (2019) developed a modelling platform to simulate karst discharge based on conceptual lumped models from the literature. Ollivier et al. (2019) integrate quantitative and qualitative factors of recharge in a reservoir model in order to simulate the spatio-temporal variability of karst recharge. Semi-distributed models were used by Chen et al. (2017b) and Hartmann et al. (2017) to study the effect of using different parameterizations of karst conduit geometry and the usability of hydrochemical information, respectively.

Generally applied by hydrogeologists, the abovementioned methods mostly focussed on characterizing the whole aquifer. Water recharge, one of the most important fluxes for balancing water budgets in karst aquifers, and the processes governing its dynamics in the vadose zone (Bakalowicz, 2005; Hartmann and Baker, 2017) have received limited attention (Berthelin and Hartmann, 2020). The vadose zone in karst systems is composed of the soil, the uppermost parts of the weathered carbonate rock (epikarst, Williams, 1983), and the unsaturated carbonate rock (Hartmann and Baker, 2017). Because of dissolution processes, the epikarst is highly altered and presents dissolution features like Karren fields and fractures. The interface between soil and rock is then irregular, and the porosity of rock decreases with depth. These characteristics lead to different hydrodynamic processes. Water in the shallow subsurface is subject to evapotranspiration. If there is soil, it can play an important role in infiltration velocity and mixing processes (Charlier et al., 2012; Perrin et al., 2003).
The heterogeneous interface between soil and epikarst and the difference in permeability between both can allow for the redistribution of the infiltrated water along the rock (Fu et al., 2015). The difference in porosity between the upper permeable rock of the epikarst and the non-weathered rock below can lead to the formation of perched aquifers (Williams, 1983) and therefore to lateral redistribution of water flow through enlarged fractures.

The rock and soil properties (porosity, fractures, lithology, karstification, etc.) are not the only factors that control recharge processes. The topography influences the water flow distribution, in particular the epikarst topography, which can have a stronger control than the surface topography itself ( Fu et al., 2015). The thickness of the shallow subsurface also influences the water flow velocity: a thin epikarst presents a higher proportion of large fractures and so a larger fraction of fast-flow components (Zhang et al., 2013). Likewise, the antecedent moisture conditions influence the storage capacity of water and infiltration rate. Under dry conditions, a larger portion of water can be stored, but subsurface flows are less important than under wet antecedent conditions (Charlier et al., 2012; Fu et al., 2015; Trček, 2007). Finally, vegetation and climate influence karst recharge processes. Recently, soil moisture was investigated in a karst area in southwest China in order to compare soil moisture variations under different vegetation conditions. According to this study, grass vegetation allows for a better storage of water in the soil compared to bare land, shrub, or forest vegetation (Zhou et al., 2019).

Approaches that were used to study soil and epikarst processes in karst mostly relied on the above-mentioned methods to study the entire karst aquifer. Zhang et al. (2013) used spring discharge observations and studied the time lag of the hydrograph response to rainfall. They showed that the time lags are much longer in the thick epikarst zone than in the thin one for short-, intermediate-, and long-term responses. Using hydrochemical methods such as major ion analyses and physiochemical parameters, Houillon et al. (2017) characterized the flow conditions in the vadose zone, where piston and dilution mechanisms were identified. Isotope analysis of water and carbon as natural tracers confirmed that the epikarst highly influences karst recharge by providing important amounts of water in a fast and concentrated form from the epikarst zone to the rest of the system (Trček, 2007). Indeed, these natural tracers can be used to investigate flow, mixing processes, and residence times in aquifers. Using artificial tracer tests, Kogovsek and Petric (2014) showed that depending on the tracer injection method, the former hydrological conditions, and the geologic heterogeneities - a rapid infiltration can happen ( $100 \mathrm{~m}$ of bedrock in hours), but most of the tracer is in fact stored within the vadose zone and progressively flushed out in a period of several years. Aley and Kirkland (2012) showed the importance of considering horizontal flow in the processes occurring within the vadose zone by using a compilation of different artificial tracer test studies. Champollion et al. (2018) found that significant water 
storage occurs in the first $10 \mathrm{~m}$ of the vadose zone when applying geophysical methods at two carbonate rock test sites in France. Most of these studies focussed on the traditional methods of karst characterization, and they were applied at individual sites at similar latitudes. Consequently, the derived understanding is difficult to transfer to other sites, e.g. to other climate regions, and more realistic conceptual models of karst recharge processes and evapotranspiration across different climates and land-use types are still missing $(\mathrm{Mu}-$ darra et al., 2019).

Here we present a soil moisture monitoring network to characterize karst recharge and evapotranspiration processes in five different climate regions, namely a tropical region (Puerto Rico), a Mediterranean region (Spain), a humid oceanic region (United Kingdom), a humid mountainous region (Germany), and a dry semi-arid region (Australia). Each site covered two land-use types (grassland and forest). The information derived from soil moisture observations from more than 400 soil moisture probes at high spatial and temporal resolutions will enable us to quantify the influence of soil and epikarst heterogeneities, as well as land-cover types, on the spatio-temporal dynamics of karstic recharge and evapotranspiration. Replicates of the measurement design at different climate conditions will allow for a qualitative comparison of the influence of climate on these processes.

\section{The monitoring concept}

Our experimental concept is designed to answer the following questions.

1. How do the soil and epikarst heterogeneities influence water flow and storage processes in the karst vadose zone?

2. What is the impact of the land-cover type on the karst system recharge and evapotranspiration?

3. How does climate influence karst system recharge and evapotranspiration?

To address these questions, we want to use standardized observations of soil moisture, which has been shown in previous studies to be informative to infer recharge processes (Ries et al., 2015).

\subsection{Selection of sites}

The experimental setup is designed to account for karstic heterogeneity and to enable the detection of lateral flow processes in the upper epikarst. It covers soil moisture dynamics of two types of land cover (grassland and forest) in five different climatic regions. The consistent setup of soil moisture monitoring at all sites allows for comparison of the soil moisture information.
Five study sites are selected across the globe (Fig. 1) in order to cover distinct climate regions: tropical, Mediterranean, humid oceanic, humid mountainous, and dry semiarid (Fig. 1, Table 1). Two plots are selected at each site in order to study the impact of vegetation on recharge: one under grassland cover and the second one under forest. On each plot, 15 soil moisture monitoring profiles are installed resulting in 90 soil moisture probes at each site, and a total number of 450 soil moisture probes at all five sites. Several criteria are considered to choose the exact location of the plots. The two plots are chosen at locations that are representative of typical grassland and forest land covers with similar slope and exposure. In order to fulfil these criteria, a geographic information system (GIS) analysis was conducted using geological maps, and digital elevation models to derive slope and exposure of the different studied karst systems. The following five sites are selected (see Fig. 1 and Sect. 2.2 for a more detailed description of the sites):

1. For Puerto Rico, El Tallonal was selected (the northern part of the island with a tropical climate).

2. For Spain, the Villanueva del Rosario karst system was selected (located $30 \mathrm{~km}$ north of Malaga, southern Spain, with a Mediterranean climate).

3. For the United Kingdom, a site at Sheepdrove Organic Farm was selected (in the south of England on the Berkshire Downs with an oceanic climate).

4. For Germany, a site in the Berchtesgaden National Park was selected (in the Northern Limestone Alps with a humid continental climate).

5. For Australia, a site above the Wellington Caves was selected (approximately $7 \mathrm{~km}$ south of the town of Wellington, southeast of Australia, with a semi-arid climate. Soil moisture deficit can be observed most of the year because of a relatively high evaporation rate and low precipitation amount.

\subsection{Site descriptions}

All of the selected sites are located at carbonate rock regions that have local or regional relevance for water resources management; they differ, however, in their surface and subsurface characteristics. A comparative overview is provided in Table 1 followed by detailed descriptions of the sites in the following subsections.

\subsubsection{The tropical site (PR)}

El Tallonal is a private natural reserve, located in the municipality of Arecibo, in the karstic zone, north of Puerto Rico $\left(18.406^{\circ} \mathrm{N}, 66.731^{\circ} \mathrm{W}\right)$. The average annual temperature is $25.5^{\circ} \mathrm{C}$; the annual precipitation is $1295 \mathrm{~mm}$. According to 


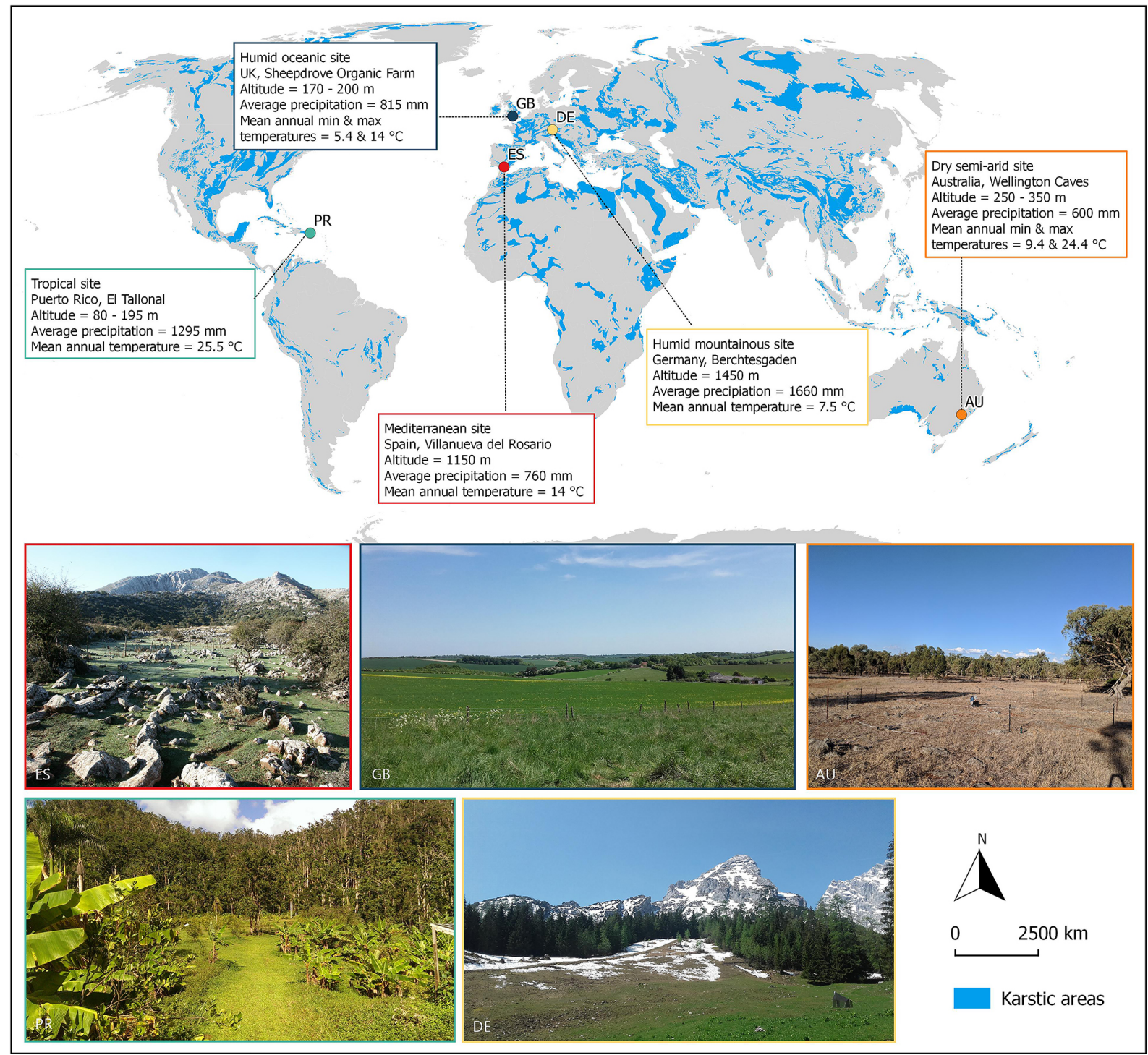

Figure 1. Locations and pictures of the five sites - carbonate rock outcrops derived from the World Karst Aquifer Map (Chen et al., 2017a).

the Holdridge life zone system (Holdridge, 1967), the reserve is classified as a subtropical moist forest zone (Ewel and Whitmore, 1973). The dominant vegetation is characterized by secondary forest, where exotic plants such as Castilla elastica (S.) and Citrus spp. Musa sp. (L.) can be found, as well as native plants such as Guarea Guidonia (L.), Casearia sylvestris (Sw.), Casearia guianensis, Urtica dioica (L.), and Roystonea borinquena (O.F.C) (Fonseca da Silva, 2014; Rivera-Sostre, 2008). The geological formation of El Tallonal reserve dates from the early Cretaceous period to the Quaternary era. The main karstic formation of the studied area is limestone of Aymamón and Aguada. These units date from the late Oligocene period and early Miocene. They are the result of several marine transgressions that happened during this period (Seiglie and Moussa, 1984; Behrensmeyer et al., 1992). Karst features are characterized by deep do- lines, separated by high hills called mogotes, being the most rugged zone of the karstic stripe (Lugo et al., 2001). The watershed is hydrologically complex and is formed by the Rio Grande de Arecibo and the Tanamá river, bounded geologically by two subwatersheds that discharge into the alluvial valley (Quiñones, 1986). The upper layer of the northern limestone aquifer is located in the Aymamón and Aguada formations, and it contains one of the most productive groundwater resources of the island. Precipitation, surface streams, and runoff recharge the aquifer. In the mogote zones, the recharge is mainly due to runoff during large precipitation events (Troester, 1999). The soil of El Tallonal karstic area is defined as a humid Oxisol with minimal and simple development of horizon according to the updated classification of Puerto Rico soil (Beinroth et al., 2003). This type of soil is clayey, with a high water retention capacity, moderate fertil- 
Table 1. Overview of site properties - MAT represents mean annual temperature; MAP represents mean annual precipitation.

\begin{tabular}{|c|c|c|c|c|c|c|}
\hline & & $\begin{array}{l}\text { Tropical region } \\
\text { (PR) }\end{array}$ & $\begin{array}{l}\text { Mediterranean } \\
\text { region (ES) }\end{array}$ & $\begin{array}{l}\text { Humid oceanic } \\
\text { region (GB) }\end{array}$ & $\begin{array}{c}\text { Humid } \\
\text { mountainous } \\
\text { region (DE) }\end{array}$ & $\begin{array}{c}\text { Dry semi-arid region } \\
\text { (AU) }\end{array}$ \\
\hline \multirow{4}{*}{ Location } & Zone & $\begin{array}{c}\text { Private natural } \\
\text { reserve - } \\
\text { municipality of } \\
\text { Arecibo-Puerto Rico }\end{array}$ & $\begin{array}{l}\text { Natural private } \\
\text { property - } 30 \mathrm{~km} \text { north } \\
\text { of Malaga - Spain }\end{array}$ & $\begin{array}{l}\text { Land of a farm - } \\
\text { Berkshire Downs } \\
\text { - England }\end{array}$ & $\begin{array}{l}\text { National park - } \\
\text { Alps - southeast } \\
\text { Germany }\end{array}$ & $\begin{array}{l}\text { Natural reserve - } 7.3 \\
\mathrm{~km} \text { south of } \\
\text { Wellington - Australia }\end{array}$ \\
\hline & $\begin{array}{l}\text { Elevation } \\
\text { Slope }\end{array}$ & $\begin{array}{c}80-195 \mathrm{~m} \\
1-8^{\circ}\end{array}$ & $\begin{array}{r}1150 \mathrm{~m} \\
0-7^{\circ}\end{array}$ & $\begin{array}{c}170-200 \mathrm{~m} \\
4-7^{\circ}\end{array}$ & $\begin{array}{l}1450 \mathrm{~m} \\
37-45^{\circ}\end{array}$ & $\frac{250-350 \mathrm{~m}}{2-4^{\circ}}$ \\
\hline & MAT & $25.5^{\circ} \mathrm{C}$ & $14{ }^{\circ} \mathrm{C}$ & $5.4-14{ }^{\circ} \mathrm{C}$ & $7.5^{\circ} \mathrm{C}$ & $9.4-24.4^{\circ} \mathrm{C}$ \\
\hline & MAP & $1295 \mathrm{~mm}$ & $760 \mathrm{~mm}$ & $815 \mathrm{~mm}$ & $1660 \mathrm{~mm}$ & $617 \mathrm{~mm}$ \\
\hline $\begin{array}{c}\text { Climatic } \\
\text { parameters } \\
\text { (Köppen- } \\
\text { Geiger } \\
\text { classification) }\end{array}$ & Climate & $\begin{array}{l}\text { Tropical climate } \\
\text { (Af) }\end{array}$ & $\begin{array}{l}\text { Mediterranean climate } \\
\text { (Csa) }\end{array}$ & $\begin{array}{l}\text { Oceanic climate } \\
\quad(\mathrm{Cfb})\end{array}$ & $\begin{array}{l}\text { Humid continental } \\
\text { climate (Dfb) }\end{array}$ & $\begin{array}{l}\text { Semi-arid climate } \\
\text { (Bsh) }\end{array}$ \\
\hline \multicolumn{2}{|c|}{ Vegetation } & $\begin{array}{c}\text { Secondary forest } \\
\text { with exotic plants as } \\
\text { Castilla elastica and } \\
\text { natives plants as } \\
\text { Guarea Guidonia }\end{array}$ & $\begin{array}{l}\text { Mediterranean } \\
\text { scrubland with } \\
\text { Mediterranean forest } \\
\text { patches and pines } \\
\text { from reforestation }\end{array}$ & $\begin{array}{l}\text { Grass, hawthorn } \\
\text { bushes, beech } \\
\text { trees, cherry trees, } \\
\text { maples }\end{array}$ & $\begin{array}{l}\text { Grass, mountain } \\
\text { pine, and green } \\
\text { alder shrubs }\end{array}$ & $\begin{array}{l}\text { Native vegetation as } \\
\text { Grassy White Box } \\
\text { woodland, exotic } \\
\text { vegetation as Wild } \\
\text { African Olive and } \\
\text { broadleaf weeds }\end{array}$ \\
\hline \multicolumn{2}{|c|}{ Geology } & $\begin{array}{l}\text { Limestone from the } \\
\text { late Oligocene } \\
\text { period and early } \\
\text { Miocene }\end{array}$ & $\begin{array}{l}\text { Carbonate rocks from } \\
\text { the Jurassic period } \\
\text { (limestones and } \\
\text { dolostones) }\end{array}$ & $\begin{array}{l}\text { White chalk from } \\
\text { the Upper } \\
\text { Cretaceous age }\end{array}$ & $\begin{array}{l}\text { Triassic Dachstein } \\
\text { limestone and } \\
\text { Ramsau dolomite }\end{array}$ & $\begin{array}{l}\text { Limestone of the } \\
\text { middle Devonian }\end{array}$ \\
\hline \multicolumn{2}{|c|}{ Hydrogeology } & $\begin{array}{l}\text { The upper layer of } \\
\text { the limestone } \\
\text { aquifer: one of the } \\
\text { most productive } \\
\text { groundwater } \\
\text { resources of the } \\
\text { island }\end{array}$ & $\begin{array}{c}\text { A fractured and } \\
\text { karstified Jurassic } \\
\text { carbonate aquifer - } \\
\text { Villanueva del Rosario } \\
\text { spring }=260 \mathrm{~L} / \mathrm{s}\end{array}$ & $\begin{array}{l}\text { White chalk } \\
\text { aquifer - } \\
\text { groundwater table } \\
\text { at tens of meters } \\
\text { depth }\end{array}$ & $\begin{array}{c}\text { Dynamic karst } \\
\text { systems drained } \\
\text { by around } 330 \\
\text { springs }\end{array}$ & $\begin{array}{l}\text { Marmorized, sub- } \\
\text { vertical, fractured } \\
\text { limestone containing } \\
\text { hypogene caves, with } \\
\text { some connectivity to } \\
\text { adjacent alluvial } \\
\text { aquifer }\end{array}$ \\
\hline \multicolumn{2}{|c|}{ Soil } & $\begin{array}{l}\text { Humid Oxisol with } \\
\text { minimal and simple } \\
\text { development of } \\
\text { horizons (Beinroth } \\
\text { et al., 2003) }\end{array}$ & $\begin{array}{l}\text { Patchy Leptosols and } \\
\text { silty-clayey texture } \\
\text { soil (Marín et al., } \\
\text { 2015) }\end{array}$ & $\begin{array}{l}\text { Grey loamy soil } \\
\text { with many flint } \\
\text { stones and pieces } \\
\text { of white chalk } \\
\text { (Iwema, 2017) }\end{array}$ & $\begin{array}{c}\text { Rendzina } \\
\text { (Nationalpark } \\
\text { Berchtesgaden, } \\
\text { 2001) }\end{array}$ & $\begin{array}{c}\text { Red-brown soil } \\
\text { comprising clays, iron } \\
\text { oxides, } \\
\text { fine quartz sands, and } \\
\text { calcite nodules, } \\
\text { with aeolian } \\
\text { contribution (Rutlidge } \\
\text { et al., 2014) }\end{array}$ \\
\hline
\end{tabular}

ity, and high acidity that can limit the growth of some species of trees (Viera et al., 2008).

Soil characterization in the field showed that roots in the soil of the grassland area concentrate in the first $15 \mathrm{~cm}$ of the soil where the texture is silty clay. Below $15 \mathrm{~cm}$ depth, the texture is more silty. We did not reach the bedrock at all grassland profiles. Thicknesses up to $9 \mathrm{~m}$ were reported by the landowner. At some profiles, we found deeper roots of Andira inermis (W.) and Musa $\times$ paradisiaca (L.) that are present all over the grassland plot. At the forest plot, we find an organic layer of more or less degraded organic matter of $20 \mathrm{~cm}$ thickness. Below, the soil texture is clay and is getting more silty with the depth (from around $20 \mathrm{~cm}$ depth). A dense network of thick and thin roots is present on the entire profile; the maximum depth reached being around $30 \mathrm{~cm}$. Soil texture analyses conducted in the laboratory show fractions of $21 \%$ of sand, $13 \%$ of silt, and $66 \%$ of clay. The primary type of tree is Coccoloba diversifolia (J.). Rock outcrops are present in the entire woodland plot.

\subsubsection{The Mediterranean site (ES)}

The Villanueva del Rosario system $\left(14 \mathrm{~km}^{2}\right.$ of catchment area) is a part of the Sierra Camarolos and Sierra del Jobo aquifer, located $30 \mathrm{~km}$ north of the city of Málaga in Spain, with altitudes from 600 to $1640 \mathrm{~m}$. The mean historic annual precipitation is below $600 \mathrm{~mm}$ in the lower altitudes of the system and more than $900 \mathrm{~mm}$ in the higher altitudes (Mudarra, 2012). The average annual temperature is around $14{ }^{\circ} \mathrm{C}$ at $700 \mathrm{~m}$ above sea level (Mudarra, 2012). The climate is temperate Mediterranean. The vegetation is Mediterranean scrubland with Mediterranean forest patches and pines from reforestation (Marín et al., 2015). Geological formations are carbonate rocks from the Jurassic period, with a maximum 
thickness of 400 to $450 \mathrm{~m}$ (Peyre, 1974). The rocks are mainly composed of limestones and, in a lower proportion, dolostones mostly found below the limestone. The aquifer is fractured and karstified, bounded at almost all its tectonic borders by Upper Triassic clays and evaporite rocks, Flysch clays and sandstones, and Cretaceous-Paleogene marls (Mudarra et al., 2014). Karst features as karren fields, dolines, uvalas, and some sinkholes are present in the entire area. The system is drained by the Villanueva del Rosario spring, located at the northwestern border of the system at $770 \mathrm{~m}$ altitude, which supplies drinking water to a nearby urbanized area. This spring has an annual mean flow discharge of $260 \mathrm{~L} \mathrm{~s}^{-1}$, and it reacts rapidly to precipitation events $(\mathrm{Mu}-$ darra et al., 2014).

The two main soil types developed at Villanueva del Rosario system are patchy Leptosols that cover carbonate outcrops with a thickness lower than $30 \mathrm{~cm}$ and silty-clayey texture soil with a thickness of 10 to $70 \mathrm{~cm}$ that covers the Cretaceous-Paleogene marls (Marín et al., 2015).

Soil characterization in the field showed that the soil in the grassland area can be divided into three horizons. The first one from $\sim 0$ to $15 \mathrm{~cm}$ depth has a silty texture. Most of the roots are concentrated at the first $\sim 10-15 \mathrm{~cm}$. The second horizon from $\sim 15$ to $40 \mathrm{~cm}$ has a silty-clayey texture. The third horizon from $\sim 40$ to $70 \mathrm{~cm}$ (maximum reached depth) has a clay texture. At some profiles, we found limestone rocks with a diameter of 10 to $30 \mathrm{~cm}$. Shrubs and rock outcrops are present all over the grassland plot. At the forest plot, we can also divide the soil into three horizons. The first one from $\sim 0$ to $10 \mathrm{~cm}$ depth has a silty texture and organic content. The second horizon from $\sim 10$ to $35 \mathrm{~cm}$ also has a silty texture. The third horizon from $\sim 35$ to $70 \mathrm{~cm}$ (maximum reached depth) has a clay texture. Grass roots (in the top $10 \mathrm{~cm}$ ) and larger roots (with a diameter $<5 \mathrm{~cm}$ ) are abundant in most of the profiles. Soil texture analyses conducted in the laboratory show fractions of $20 \%$ of sand, $64 \%$ of silt, and $15 \%$ of clay. In addition, the analyses confirm that the soil is getting more clayey with the depth, reaching a proportion of $72 \%$ of clay at the grassland plot and $33 \%$ of clay at the forest plot. Trees (Quercus ilex (L.), Quercus faginea (L.), and Crataegus monogyna (J.)) and rock outcrops are present in the entire woodland plot.

\subsubsection{The humid oceanic site (GB)}

The UK site is located on the property of Sheepdrove Organic Farm, at the Berkshire Downs (southern England). The mean annual minimum and maximum temperature values are 5.4 and $14.0^{\circ} \mathrm{C}$, respectively. The annual average precipitation is $815 \mathrm{~mm}$. The climate is classified as oceanic. The area is composed of meadow and forest with species such as hawthorn bushes, beech trees, cherry trees, and maples (Iwema, 2017). The study area is located in the Lambourn catchment, where the main geological formation is the Chalk Group of Upper Cretaceous age (Wheater et al., 2007). The white Chalk Group formation is the principal aquifer of the region. It is highly permeable and karstified with dry valleys that run perpendicular to the Lambourn River, and it has a groundwater table at tens of metres depth (Wheater et al., 2007; Rahman and Rosolem, 2017).

The soil is a grey, loamy soil with many flint stones of up to $20 \mathrm{~cm} \times 20 \mathrm{~cm} \times 5 \mathrm{~cm}$ and pieces of white chalk (Iwema, 2017).

Soil characterization in the field showed that the soil at the grassland area can be divided into two horizons. The first ranges from $\sim 0$ to $10 \mathrm{~cm}$ depth and has a silty texture with most of the roots concentrated in this layer. The second horizon starts from $\sim 10 \mathrm{~cm}$ to various depths and has a silty texture with pieces of chalk (diameter $<2 \mathrm{~cm}$ ) and flint stones (diameter $>6 \mathrm{~cm}$ ). The occurrence of roots and flint stones decreases with depth, and the number of chalk stones, as well as the soil density, increases with depth. White chalk bedrock appears at almost all profiles between $\sim 30 \mathrm{~cm}$ and up to $60 \mathrm{~cm}$, depending on the location, with a continuous transition between the soil and chalk. At the forest plot, there is a $5-10 \mathrm{~cm}$ organic layer. Small roots are observed until $\sim 10 \mathrm{~cm}$ depth. Thicker roots are also abundant across the entire soil depth for most of the profiles. A very soft chalk layer is found at almost all profiles at variable depths from $\sim 10 \mathrm{~cm}$ to $35 \mathrm{~cm}$. The horizon from $\sim 5 \mathrm{~cm}$ to the chalk layer has a silty texture. Some chalk stones (diameter $<2 \mathrm{~cm}$ ) and flint stones (diameter $>6 \mathrm{~cm}$ ) can be found. The occurrence of chalk stones increases with the depth and leads to a continuous transition between the soil and chalk layer. Soil texture analyses conducted in the laboratory show fractions of $24 \%$ of sand, $47 \%$ of silt, and $39 \%$ of clay.

\subsubsection{The humid mountainous site (DE)}

The Berchtesgaden Land site is part of a national park located in the Northern Limestone Alps in southeast Germany. The average annual temperature is $7.5^{\circ} \mathrm{C}$, and the annual average precipitation varies between 1500 and $2600 \mathrm{~mm}$, depending on the altitude. The minimum altitude in the national park is $603 \mathrm{~m}$, and the maximum altitude is at $2713 \mathrm{~m}$. The climate is classified as humid continental.

The type of vegetation found in the park is grass, mountain pine, and green alder shrubs (Garvelmann et al., 2017).

The dominant geological formation of the Berchtesgaden Land is Triassic Dachstein limestone and Ramsau dolomite. Jurassic and Cretaceous rock series are also present in the area. Karstification took place since the Alpine thrust exposed the limestone and typical karst features can be found as sinkholes, dry stream, caves, etc. Three valleys are drained by rivers from south to north and contribute to the Danube watershed (Kraller et al., 2011). The karst systems that can be found in the area are drained by around 330 springs, with a discharge from a few litres per second to several hundred litres per second. Most of them are located at the interface of the limestone and dolomite rock (Kraller et al., 2011). In 
the area of the national park, three main types of soil can be found: Syrosem (35.5\%), Cambisol (30.1\%), and Podsol (26.7\%) (Garvelmann et al., 2017).

The plots are located at an altitude of $1450 \mathrm{~m}$ with a mean annual precipitation of $1660 \mathrm{~mm}$. The snow cover in this area is present from mid-November to the end of April or beginning of May. Soil characterization in the field showed that the soil in the grassland area can be divided into three horizons. The first one from $\sim 0$ to $15 \mathrm{~cm}$ depth presents a high organic content. Most of the roots are concentrated at the first $\sim 10$ $15 \mathrm{~cm}$. At some profiles, roots can be found in the entire profile down to $\sim 50 \mathrm{~cm}$ soil depth. The second horizon from $\sim 15$ to $50 \mathrm{~cm}$ has a silty-clayey texture. The third horizon from $\sim 50$ to 60 contains less clay than the previous horizon. The second and third horizon thicknesses are highly variable, depending on the profile location. Indeed, at the bottom of the soil profiles, from $\sim 15$ to $\sim 65 \mathrm{~cm}$, we find the bedrock to be composed of limestone rock pieces (diameter $<5$ to $>15 \mathrm{~cm}$ ) mixed with sand. Some young, growing pines $(<1 \mathrm{~m})$ are present all over the grassland plot. At the forest plot, we can also divide the soil into three horizons. The first one from $\sim 0$ to $20 \mathrm{~cm}$ depth has a high organic content. Grass roots (in the top $10 \mathrm{~cm}$ ) and larger roots (diameter $<5 \mathrm{~cm}$ ) are abundant in most of the profiles. The second horizon from $\sim 20$ to $30 \mathrm{~cm}$ has a clay texture. The third horizon from $\sim 30$ to $50 \mathrm{~cm}$ is getting brighter with a clay texture. Soil texture analyses conducted in the laboratory show fractions of $11 \%$ of sand, $68 \%$ of silt, and $21 \%$ of clay. In addition, the analyses confirm that the soil is getting more clayey with the depth, reaching a proportion of clay of up to $55 \%$. The second and third horizon thicknesses are also highly variable depending on the profile location. The same rocky layer is observed at the bottom of the soil profiles. Trees, such as spruce and larch, and rocks are present in the entire woodland plot.

\subsubsection{The dry semi-arid site (AU)}

The Wellington Caves site is a reserve located on the eastern side of the Catombal Range, and it is adjacent to the Bell River valley and alluvial aquifer, $7.3 \mathrm{~km}$ south of the town of Wellington $\left(32.624^{\circ} \mathrm{S}, 148.936^{\circ} \mathrm{E}\right)$. Wellington Caves are an important regional tourist resource. The annual average rainfall at Wellington is $\sim 620 \mathrm{~mm}$, and the annual PET is $\sim 1800 \mathrm{~mm}$. The annual temperature ranges from around 0 to $45^{\circ} \mathrm{C}$ with a maximum mean annual temperature of $24.3^{\circ} \mathrm{C}$. The climate is classified as temperate semi-arid (Markowska et al., 2016).

The native Australian Grassy White Box woodland dominates the vegetation, including the forest site. At the limestone outcrops, tree species such as Brachychiton populneus (S. \& E.) (Kurrajong), Callitris endlicheri (P.) (Black Cypress), Callitris glaucophylla (T. \& J.) (White Cypress), and Eucalyptus albens (B.) (White Box), can be found (Jex et al., 2012). Exotic vegetation is also present: wild African olive can be found at the immediate surface above the caves and has historically been present at the forest site.

The geology of the reserve is composed of deep-water marine sediments of the Ordovician Oakdale Formation and of limestone of the middle Devonian Garra Formation. The Oakdale Formation is present in a narrow band in the eastern part of the reserve. The Garra Formation is present is the rest of the reserve. The Garra Formation limestone is locally marmorized, sub-vertically folded, and composed of both massive and thinly bedded limestone with abundant marine fossils (Keshavarzi et al., 2017). Most of the significant karst features are developed in the massive limestone and have evidence of hypogene formation (Osborne, 2007). Both the forest and grass sites are situated on the massive limestone.

The Bell River is located around $700 \mathrm{~m}$ west of the caves, with the river alluvium adjacent to the Garra limestone. The potential connectivity between the river and the karst aquifer is high (Keshavarzi et al., 2017). Otherwise, no permanent streams can be found on the reserve. Adjacent to the forest site, and within Cathedral Cave, a network of drip loggers have been recording diffuse recharge at two depths $(\sim 4$ and $\sim 25 \mathrm{~m}$ ) in the Garra Formation limestone since 2011. The logger network is described in Jex et al. (2012), and time series for diffuse recharge can be found in Cuthbert et al. (2014) and Markowska et al. (2016). According to Jex et al. (2012), recharge happens if rainfall is at least around $60 \mathrm{~mm}$ within a 24-48 $\mathrm{h}$ period, depending on soil moisture antecedent conditions.

The soil in the reserve is generally thin $(<1 \mathrm{~m}$ depth). Soil characterization in the field showed that, at both the forest and the grassland sites, the soils were backed dry.

The soil in the grassland area presents most roots at the first $\sim 5 \mathrm{~cm}$. At deeper layers (below $5 \mathrm{~cm}$ ), we find a sandy clay texture followed directly by carbonate rock in most of the cases. At some profiles, we found some larger rocks that could be part of the soil skeleton or the beginning of the bedrock. At the woodland plot, we find a cover of partly degraded organic matter at the first $\sim 5 \mathrm{~cm}$. Below, until $\sim 20 \mathrm{~cm}$ of depth, we find a clay soil and thicker roots. Below $\sim 20 \mathrm{~cm}$, an increasing fraction of rocks appears, indicating the beginning of the carbonate rock. Soil texture analyses conducted in the laboratory show fractions of $13 \%$ of sand, $21 \%$ of silt, and $66 \%$ of clay. Thick roots are abundant in most of the profiles. Trees (Eucalyptus albens (B.)) and rock outcrops are present in the entire woodland plot.

\subsection{Selection and setup of plots with contrasting land-cover types}

At each site, we defined two plots of $400 \mathrm{~m}^{2}$ each in order to representatively capture the variability in epikarst heterogeneities. A larger area would not capture the spatial correlation of soil moisture dynamics between the soil moisture profiles; a smaller area would miss the spatial heterogeneity of epikarst that drives lateral soil water redistribution. At all 
plots, we defined squares of $20 \mathrm{~m}$ by $20 \mathrm{~m}$, except for the UK grassland plot that is $32 \mathrm{~m}$ by $12 \mathrm{~m}$ due to restrictions by the landowner. Fifteen locations within each plot were randomly chosen for the installation of the soil moisture profiles (random sampling of profile locations from a uniform distribution) in order to cover a wide range of distances (i.e. potential characteristic length scales) between the 15 profiles. At each profile, three probes at three different depths were installed, namely at $5 \mathrm{~cm}, 10 \mathrm{~cm}$, and at the boundary between the soil and bedrock. The upper two probes are expected to measure the soil moisture signal that is predominantly controlled by vertical infiltration and evapotranspiration processes, while the soil moisture dynamics observed by the lowest probe can also be affected by lateral subsurface redistribution processes within the epikarst. The installation procedure did not allow for installation at depths $>80 \mathrm{~cm}$. In such cases, the probe was installed at this maximum depth without reaching the epikarst.

Figure 2 shows the location of the grassland and forest plot for the Mediterranean climate site, with a diagram that represents the distribution of the profile and their connection with the data logger. The two plots are close to each other in order to have similar weather conditions, slope, and exposure. This is the same for all sites, except for the UK where the plots are $\sim 1.5 \mathrm{~km}$ apart from each other due to restrictions by the landowner.

With the locations of all profiles defined, soil pits with a diameter of around $25 \mathrm{~cm}$ (to push the probes into the soil) and depth preferably down to the epikarst were drilled using hand tools and a gasoline driller, which allowed for maximum depths of $\sim 80 \mathrm{~cm}$. For some locations, we did not reach the epikarst $(18,23$, and 2 cases at the tropical climate site, the Mediterranean site, and the humid oceanic climate site, respectively). For some locations, the soil was too thin and fewer probes had to be installed $(1,1$, and 14 cases at the tropical climate site, the humid oceanic site, and the dry semi-arid climate site, respectively). During installation, the characteristics of the soil and the orientation of the probes were recorded for each profile. The cables of the probes were protected by cable conduits and connected to the loggers, which are located at a central position of the plots (Fig. 2). At each plot, we use two loggers in order to achieve manageable lifetimes of the batteries and to avoid storage overflow of the loggers (see next subsection). In some cases, we applied additional protection measures at the plots. For example, a fence was necessary for the dry semi-arid climate grassland plot to prevent kangaroo damage. In the first months of logging, further damage occurred from wild boars (Mediterranean climate site), martens (humid mountainous site), or humidity (tropical climate site), which required further protection measures.

At each site, a weather station is installed close to the plots. Precipitation is measured at different temporal resolutions depending on the site, depending on energy supply and storage capacities. For the tropical climate site, the temporal
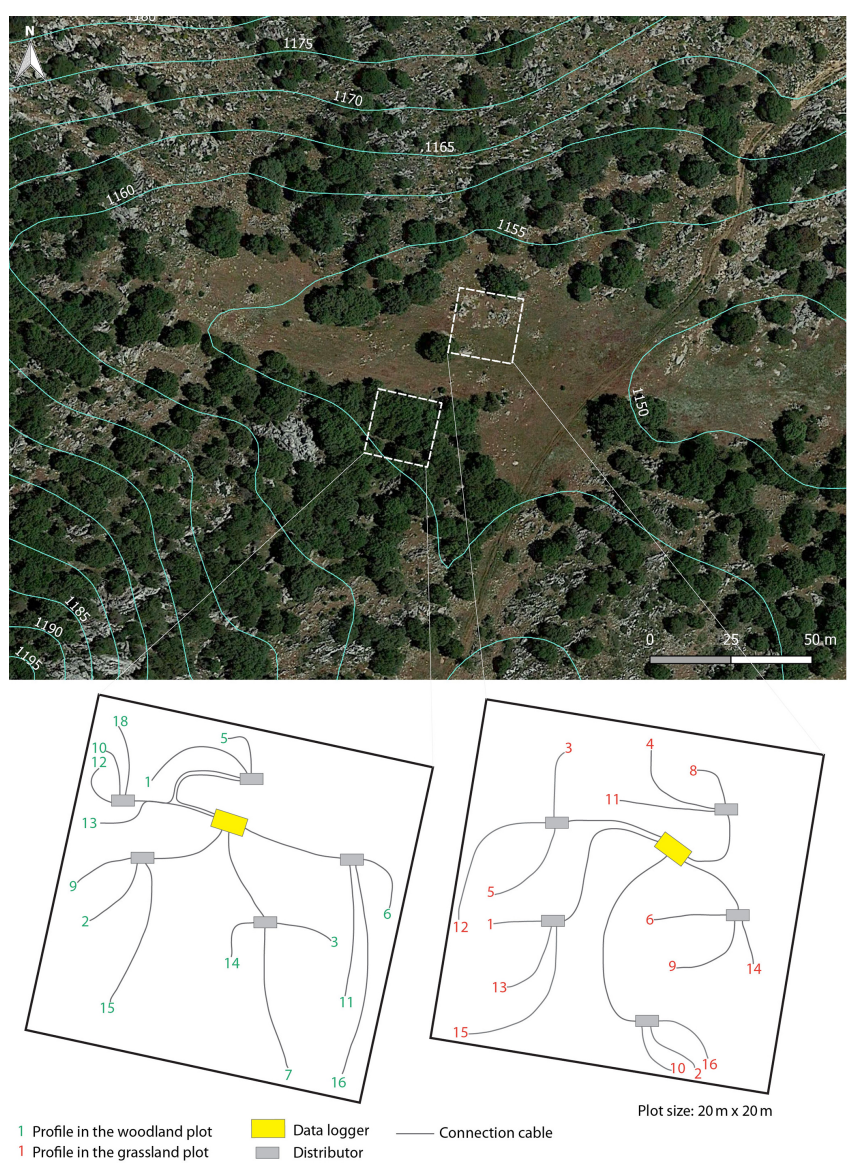

Figure 2. Plot locations, profile distributions, and cable connection maps at the Spanish site. The yellow boxes represent the data loggers. The grey boxes represent the distributors from Truebner $\mathrm{GmbH}$ that allow for the connection of 11 probes to one connection of the logger (one logger has four connections). Map data: (C) 2015 Google.

resolution is $5 \mathrm{~min}$. For the humid mountainous and dry semiarid sites, the resolution is $10 \mathrm{~min}$. For the Mediterranean one, it is $15 \mathrm{~min}$, and it is $1 \mathrm{~h}$ for the humid oceanic climate site. Discharge is monitored at some of the sites (tropical, Mediterranean, humid mountainous, and dry semi-arid). Although sometimes unavailable, these data may allow for the determination of the link between the discharge and the soil moisture signal.

\subsection{Technical description of probes and loggers}

We used the soil moisture sensor "SMT100" from Truebner GmbH (Fig. 3), which combines the advantages of a frequency-domain reflectometry (FDR) sensor systems with the accuracy of a time-domain reflectometry (TDR) system. Its measurement is based on the travel time of a signal to determine the dielectric constant of the soil. For each of our plots, we used two "TrueLog100" (Fig. 3) data loggers, except for Puerto Rico where we used four loggers to enhance 


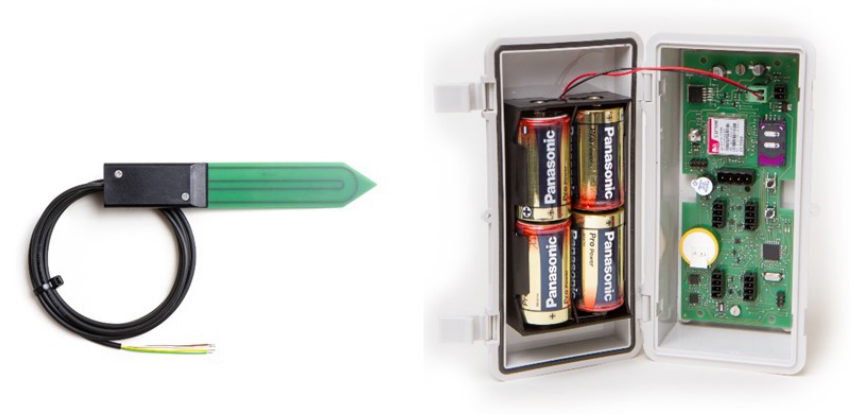

Figure 3. Picture of the soil moisture sensors SMT100 and the data logger TrueLog100 from Truebner GmbH.

the battery life span. The data logger is powered with four $\mathrm{D}$ cell alkaline batteries and can be used for up to 50 sensors (in our a case maximum of 27). We programmed the data logger to take measurements with a time resolution of $15 \mathrm{~min}$. This allows for the coverage of rapid infiltration with a manageable life span of the batteries even during cold conditions (57 months) without data storage overflow (320000 measurements capacity, including water content, permittivity, counts, temperature, and voltage supply in one measurement).

The number of probes per site $(\sim 90)$ and in total (over 400) allows for new insights into the spatio-temporal variability of soil moisture dynamics at our sites. We used the manufacturer's calibration and not a site-specific calibration, because we were mainly interested in the dynamics of soil moisture rather than their absolute values (see also Sprenger et al., 2015; Demand et al., 2019). Even without calibration, an observed increase in soil moisture will go along with infiltration, and a plateau of very high soil moisture values can be seen as an indicator of saturation.

\section{First observations}

Figure 4 shows the first observations of soil moisture responses to individual rainfall events at selected profiles at the five sites: one profile in the grassland plot and one profile at the forest plot for each site. These examples show a broad range of soil moisture reactions. At the tropical site in the forest, we can observe that the deepest probe ( $21 \mathrm{~cm}$ soil depth) reacts strongest, in comparison to the two shallower ones (5 and $10 \mathrm{~cm}$ soil depth). We can also observe that a plateau is reached, which indicates soil saturation. Despite the differences in the soil properties at the grassland plot (Sect. 2.2), we can observe a quite similar behaviour as in the forest (with probes at depths 5, 10, and $50 \mathrm{~cm}$ ). At the Mediterranean site at the grassland, the shallowest probe at $5 \mathrm{~cm}$ soil depth reacts first, then the second at $10 \mathrm{~cm}$ depth with some attenuation, and the deepest probe $(38 \mathrm{~cm}$ soil depth) does not react at all. However, at the forest plot, the deepest probe $(34 \mathrm{~cm}$ soil depth) responds stronger than the others do. Despite the dry period during which this first example was recorded, we still can observe a response of soil moisture at the soil-bedrock interface.

The profile shown for the humid oceanic grassland plot reacts very similarly to the Mediterranean grassland plot: the first probe to react is the shallowest $(5 \mathrm{~cm}$ soil depth), followed by the second at $10 \mathrm{~cm}$ soil depth. The deepest probe at the limit between the soil and the chalk ( $45 \mathrm{~cm}$ soil depth) is not reacting. The dynamics of the second probe are attenuated compared to the first. At the forest plot, the deepest probe $(26 \mathrm{~cm}$ soil depth) is reacting stronger than the two shallower probes. At the humid mountainous site, we find a consecutive reaction pattern at both the grassland plot and the forest plot with a first soil moisture response at the shallowest probe at $5 \mathrm{~cm}$ soil depth, followed iteratively by the deeper probes (43 and $20 \mathrm{~cm}$ soil depths, respectively). At the grassland plot of the dry semi-arid site, the shallowest probe at $5 \mathrm{~cm}$ soil depth reacts first, followed by the second at $10 \mathrm{~cm}$ soil depth, and the deepest one at $20 \mathrm{~cm}$ depth. An attenuation of the reaction is clearly observed with increasing depth. At the forest plot, the deepest probe at $15 \mathrm{~cm}$ depth responds stronger than the shallowest ones at 5 and $10 \mathrm{~cm}$ soil depths.

Although work is still in progress, the observations shown above already give a glance at the different flow processes that might happen at our sites and plots. At some of the profiles, the deepest probes do not react. In such cases, we can assume that a part of the water was evaporated or taken up by the vegetation, or the infiltrating water did not reach the lowest probe because of slow infiltration, water storage, or lateral redistribution. This could be the case of the response presented in Fig. 4 for the Mediterranean, humid oceanic, and dry semi-arid grassland profiles. At other profiles, we find a sequential reaction of all probes: the deepest probes respond with a delay compared to the upper ones and in an attenuated way. In this case, we could assume that infiltration is rather homogeneous (Demand et al., 2019) and that a part of the water is reaching the deeper subsurface to eventually contribute to groundwater recharge. This could be the case for the humid mountainous profiles presented in Fig. 4. On the other hand, we find non-sequential reactions at other profiles, indicating a rather heterogeneous soil structure (Demand et al., 2019) with preferential flow path that can lead to rapid recharge dynamics (Ries et al., 2015) and quick discharge responses (Chifflard et al., 2019) during heavy rainfall events. Still at the stage of preliminary analyses, these potential interpretations of flow dynamics have to be explored with more detailed analyses when longer time series are available. Furthermore, additional information on recharge processes will be extracted from analyses that include precipitation and discharge data. 


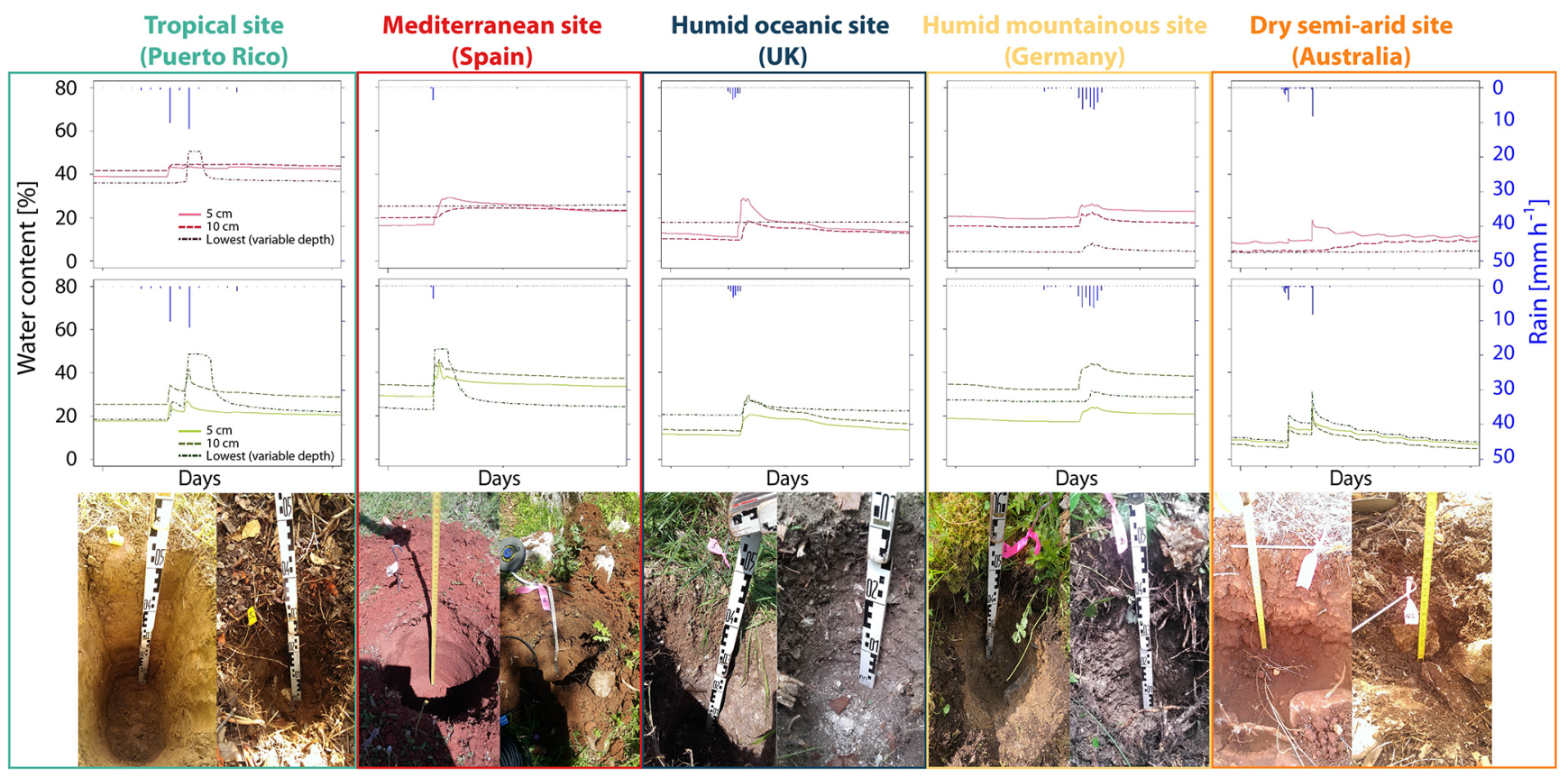

Figure 4. Examples of observed soil moisture dynamics at each site (example events for selected profiles). The top graphs with the red curves show the reaction of the probes at the grassland plots. The bottom graphs with the green curves show the reaction of the probes at the forest plots. The photos on the bottom row show the soil profiles of the respective plots (left is grassland plot, right is forest plot).

\section{Synthesis}

In this work, we presented the objectives, measuring concept, and implementation of a soil moisture monitoring network at five representative sites across the globe to characterize karstic groundwater recharge and evapotranspiration processes. The monitoring network aims at improving the understanding of (1) the influence of soil and epikarst heterogeneities in karst regions on the flow and storage processes in the karst vadose zone, (2) the impact of land cover on karstic groundwater recharge and evapotranspiration, and (3) the qualitative climatic impacts on karstic groundwater recharge and evapotranspiration. In order to address these research objectives, more than 400 soil moisture probes were installed at five study sites located within different climatic regions. Each soil profile consisted of three probes in 5, 10, and $80 \mathrm{~cm}$ depths (or at the soil-bedrock interface, when the soils were shallower). In order to account for the effect of different land covers, the profiles at each of the five sites were equally split between a grassland plot and a forest plot, each with an extent of $20 \mathrm{~m}$ by $20 \mathrm{~m}$. Although limited to a few rainfall or soil moisture events sampled so far, our preliminary data already reveal different soil moisture responses at the different sites and land-use types, such as sequential (top to bottom) reactions of soil moisture to rainfall events that can favour evapotranspiration and non-sequential reactions indicating subsurface heterogeneity and preferential pathways that can result in enhanced groundwater recharge.
The wide range of local heterogeneities, land-cover types, and climate regions will allow new and detailed insights into the dynamics of groundwater recharge and evapotranspiration at the shallow subsurface in karstic regions. With longer records, additional data analysis will allow for investigating the sequences of reactions of all available soil profiles (Demand et al., 2019), the identification of characteristic soil moisture states (Martini et al., 2015), and the quantitative assessment of soil hydraulic properties, evapotranspiration, and recharge rates by physically based soil models (Sprenger et al., 2015). The measuring network will provide comprehensive data to develop and test new conceptual models of the functioning of the soil and epikarst, depending on climate and land use (Enemark et al., 2019). These data will help to improve the realism of water resource models for karst regions (Mudarra et al., 2019), the quantification of land-use change effects on karstic recharge (Sarrazin et al., 2018), or the simulation of above-cave hydrology for improved speleothem palaeoclimate reconstruction (Hartmann and Baker, 2017; Cuthbert et al., 2014).

It is planned to maintain the monitoring network for periods longer than the funding time of this project (3 years), depending on future funding and local support. When several hydrological years are recorded, we will make our data publicly available through a data publication in order to contribute to international efforts like the Critical Zone Observatories (Anderson et al., 2016), the International Soil Moisture Network (Dorigo et al., 2011), or initiatives to improve global earth systems models (Fan et al., 2019). 
Data availability. The preliminary data shown in this article are available upon request to the authors.

Author contributions. The research and monitoring programme was designed and implemented by RB with advice from AH, MM, and MR. The paper was conceived by RB and guided by $\mathrm{AH}$ and MR. BA, AB, DK, GL, AL, KL, MM, IYP, FPA, RR, and AV provided their local expertise before, after, and during the installation of the soil moisture network, as well as during the conception of the description of the study sites.

Competing interests. The authors declare that they have no conflict of interest.

Acknowledgements. Matías Mudarra and Bartolomé Andreo were supported by the research group RNM-308 funded by the Regional Government of Andalusia (Spain) and project CGL2015-65858$\mathrm{R}$ founded by the General Office of Scientific and Technical Research (DGICYT) of the Spanish Government. Rafael Rosolem is supported by "A MUlti-scale Soil moisture Evapotranspiration Dynamics study" (AMUSED) (grant number NE/M003086/1) and the "Brazilian Experimental datasets for MUlti-Scale interactions in the critical zone under Extreme Drought" (BEMUSED) (grant number NE/R004897/1); both projects were funded by the Natural Environment Research Council (NERC). The article processing charge was funded by the German Research Foundation (DFG) and the University of Freiburg in the funding programme Open Access Publishing. We thank Martin Maier for his advice concerning the soil description.

Financial support. This research has been supported by the Emmy Noether Programme of the German Research Foundation (grant no. HA 8113/1-1).

Review statement. This paper was edited by Salvatore Grimaldi and reviewed by two anonymous referees.

\section{References}

Aley, T. J. and Kirkland S. L.: Down but Not Straight down: Significance of Lateral Flow in the Vadose Zone of Karst Terrains, Carbonate. Evaporite., 27, 193-98, https://doi.org/10.1007/s13146012-0106-5, 2012.

Anderson, S., Brantley, S., Derry, L., Dietrich, W., Grant, G., Hart, S., Kumar, P., Lohse, K., McDowell, W., McIntosh, J., Moloch, N., Papanicolaou, T., Richardson, J., Richter, D., Riebe, C., Russo, T., Seyfried, M., Thompson, S., and White, T.: A Strategy for Advancing Critical Zone Science, CZO Strategy Meeting, Boulder, 3-5 February 2016, Colorado, 2016.

Bakalowicz, M.: Karst groundwater: a challenge for new resources, Hydrogeol. J., 13, 148-160, https://doi.org/10.1007/s10040-0040402-9, 2005.
Behrensmeyer, A. K., Darmuth, J. D., DiMichele, W. A., Pots, R., Sues, H. D., and Wing, S. L.: Terrestrial Ecosystems through Time, Chicago, IL, The University of Chicago Press, 1992.

Beinroth, F. H, Engel, R. J., Lugo, J. L., Santiago, C. L., Ríos, S., and Brannon, G. R.: Updated Taxonomic Classification of the Soils of Puerto Rico, 2002, Bull. 303, Univ. Puerto Rico, Agric. Experiment Station, Río Piedras, P.R., 2003.

Berthelin, R. and Hartmann, A.: The Shallow Subsurface of Karst Systems: Review and Directions, in: Eurokarst 2018, Besançon. Advances in Karst Science, edited by: Bertrand, C., Denimal, S., Steinmann, M., and Renard, P., 11, 61-68, Springer, Cham, https://doi.org/10.1007/978-3-030-14015-1_7, 2020.

Chalikakis, K., Plagnes, V., Guerin, R., Valois, R., and Bosch, F. P.: Contribution of Geophysical Methods to Karst-System Exploration: An Overview, Hydrogeol. J., 19, 1169-1180, https://doi.org/10.1007/s10040-011-0746-x, 2011.

Champollion, C., Deville, S., Chéry, J., Doerflinger, E., Le Moigne, N., Bayer, R., Vernant, P., and Mazzilli, N.: Estimating epikarst water storage by time-lapse surface-to-depth gravity measurements, Hydrol. Earth Syst. Sci., 22, 3825-3839, https://doi.org/10.5194/hess-22-3825-2018, 2018.

Charlier, J. B., Bertrand, C., and Mudry, J.: Conceptual Hydrogeological Model of Flow and Transport of Dissolved Organic Carbon in a Small Jura Karst System, J. Hydrol., 460-461, 52-64, https://doi.org/10.1016/j.jhydrol.2012.06.043, 2012.

Chen, Z., Auler, A. S., Bakalowicz, M., Drew, D., Griger, F., Hartmann, J., Jiang, G., Moosdorf, N., Richts, A., Stevanovic, Z. Veni, G., and Goldscheider, N.: The World Karst Aquifer Mapping Project: Concept, Mapping Procedure and Map of Europe, Hydrogeol. J., 25, 771-785, https://doi.org/10.1007/s10040-0161519-3, 2017a.

Chen, Z., Hartmann, A., and Goldscheider, N.: A new approach to evaluate spatiotemporal dynamics of controlling parameters in distributed environmental models, Environ. Modell. Softw., 87, 1-16, https://doi.org/10.1016/j.envsoft.2016.10.005, 2017b.

Chifflard, P., Blume, T., Maerker, K., Hopp, L., Meerveld, I., Graef, T., Gronz, O., Hartmann, A., Kohl, B., Martini, E., ReinhardtImjela, C., Reiss, M., Rinderer, M., and Achleitner, S.: How Can We Model Subsurface Stormflow at the Catchment Scale If We Cannot Measure It?, Hydrol. Process., 33, 1378-1385, https://doi.org/10.1002/hyp.13407, 2019.

Cuthbert, M. O., Baker, A., Jex, C. N., Graham, P. W., Treble, P. C., Andersen, M. S., and Acworth, R. I.: Drip Water Isotopes in Semi-Arid Karst: Implications for Speleothem Paleoclimatology, Earth Planet. Sc. Lett., 395, 194-204, https://doi.org/10.1016/j.epsl.2014.03.034, 2014.

Demand, D., Blume, T., and Weiler, M.: Spatio-temporal relevance and controls of preferential flow at the landscape scale, Hydrol Earth Syst. Sci., 23, 4869-4889, https://doi.org/10.5194/hess-234869-2019, 2019.

Dorigo, W. A., Wagner, W., Hohensinn, R., Hahn, S., Paulik, C., Xaver, A., Gruber, A., Drusch, M., Mecklenburg, S., van Oevelen, P., Robock, A., and Jackson, T.: The International Soil Moisture Network: a data hosting facility for global in situ soil moisture measurements, Hydrol. Earth Syst. Sci., 15, 1675-1698, https://doi.org/10.5194/hess-15-1675-2011, 2011.

Enemark, T., Peeters, L. J. M., Mallants, D., and Batelaan, O.: Hydrogeological Conceptual Model Build- 
ing and Testing: A Review, J. Hydrol., 569, 310-329, https://doi.org/10.1016/j.jhydrol.2018.12.007, 2019.

Ewel, J. J. and Whitmore, J. L.: The Ecological Life Zones of Puerto Rico and the U.S. Virgin Islands, SDA Forest Service, Institute of Tropical Forestry, Research Paper ITF-018, 1973.

Fan, Y., Clark, M., Lawrence, D. M., Swenson, S., Band, L. E., Brantley, S. L., Brooks, P. D., Dietrich, W. E., Flores, A., Grant, G., Kirchner, J. W., Mackay, D. S., McDonnell, J. J., Milly, P. C. D., Sullivan, P. L., Tague, C., Ajami, H., Chaney, N., Hartmann, A., Hazenberg, P., McNamara, J., Pelletier, J., Perket, J., Rouholahnejad-Freund, E., Wagener, T., Zeng, X., Beighley, E., Buzan, J., Huang, M., Livneh, B., Mohanty, B. P., Nijssen, B., Safeeq, M., Shen, C., Verseveld, W., Volk, J., and Yamazaki, D.: Hillslope Hydrology in Global Change Research and Earth System Modeling, Water Resour. Res., 55, 1737-1772, https://doi.org/10.1029/2018WR023903, 2019.

Fonseca da Silva, J.: Species Composition, Diversity and Structure of Novel Forests of Castilla Elastica in Puerto Rico, Tropical Ecology, 55, 231-244, 2014.

Ford, D. C. and Williams, P. W.: Karst Hydrogeology and Geomorphology, John Wiley \& Sons, Chichester, 2007.

Fu, Z. Y., Chen, H. S., Zhang, W., Xu, Q. X., Wang, S., and Wang, K. L.: Subsurface Flow in a Soil-Mantled Subtropical Dolomite Karst Slope: A Field Rainfall Simulation Study, Geomorphology, 250, 1-14, https://doi.org/10.1016/j.geomorph.2015.08.012, 2015.

Garvelmann, J., Warscher, M., Leonhardt, G., Franz, H., Lotz, A., and Kunstmann, H.: Quantification and Characterization of the Dynamics of Spring and Stream Water Systems in the Berchtesgaden Alps with a Long-Term Stable Isotope Dataset, Environ. Earth Sci., 76, 766, https://doi.org/10.1007/s12665-017-7107-6, 2017.

Giese, M., Reimann, T., Bailly-Comte, V., Maréchal, J. C., Sauter, M., and Geyer, T.: Turbulent and Laminar Flow in Karst Conduits Under Unsteady Flow Conditions: Interpretation of Pumping Tests by Discrete Conduit-Continuum Modeling, Water Resour. Res., 54, 1918-1933, https://doi.org/10.1002/2017WR020658, 2018.

Goldscheider, N. and Drew, D.: Methods in Karst Hydrogeology, Taylor \& Francis Group, Leiden, NL, 2007.

Goldscheider, N., Meiman, J., Pronk, M., and Smart, C.: Tracer Tests in Karst Hydrogeology and Speleology, Int. J. Speleol., 37, 27-40, https://doi.org/10.5038/1827-806X.37.1.3, 2008.

Hartmann, A. and Baker, A.: Modelling Karst Vadose Zone Hydrology and Its Relevance for Paleoclimate Reconstruction, Earth-Sci. Rev., 172, 178-192, https://doi.org/10.1016/j.earscirev.2017.08.001, 2017.

Hartmann, A., Goldscheider, N., Wagener, T., Lange, J., and Weiler, M.: Karst Water Resources in a Changing World: Review of Hydrological Modeling Approaches: KARST WATER RESOURCES PREDICTION, Rev. Geophys., 52, 218-242, https://doi.org/10.1002/2013RG000443, 2014.

Hartmann, A., Barberá, J. A., and Andreo, B.: On the value of water quality data and informative flow states in karst modelling, Hydrol. Earth Syst. Sci., 21, 5971-5985, https://doi.org/10.5194/hess-21-5971-2017, 2017.

Holdridge, L. R.: Life Zone Ecology, San José, Costa Rica: Tropical Science Center, 1967.
Houillon, N., Lastennet, R., Denis, A., and Malaurent, P.: Hydrochemical and Hydrodynamic Behavior of the Epikarst at the Lascaux Cave (Montignac, France), in: EuroKarst 2016, Neuchâtel, edited by: Renard, P. and Bertrand, C., Advances in Karst Science, Springer International Publishing, 319-326, 2017.

Iwema, J.: Opportunities and Limitations of the Cosmic-Ray Neutron Soil Moisture Sensor under Humid Conditions, University of Bristol, UK, 2017.

Jex, C., Mariethoz, G., Baker, A., Graham, P., Andersen, M. Acworth, I., Edwards, N., and Azcurra, C.: Spatially Dense Drip Hydrological Monitoring and Infiltration Behaviour at the Wellington Caves, South East Australia, Int. J. Speleol., 41, 283296, https://doi.org/10.5038/1827-806X.41.2.14, 2012.

Keshavarzi, M., Baker, A., Kelly, B. F. J., and Andersen, M. S.: River-Groundwater Connectivity in a Karst System, Wellington, New South Wales, Australia, Hydrogeol. J., 25, 557-574, https://doi.org/10.1007/s10040-016-1491-y, 2017.

Kogovsek, J. and Petric, M.: Solute Transport Processes in a Karst Vadose Zone Characterized by Long-Term Tracer Tests (the Cave System of Postojnska Jama, Slovenia), J. Hydrol., 519, 12051213, https://doi.org/10.1016/j.jhydrol.2014.08.047, 2014.

Kraller, G., Strasser, U., and Franz, H.: Effect of Alpine Karst on the Hydrology of the Berchtesgadener Ache Basin?: A Comprehensive Summary of Karst Research in the Berchtesgaden Alps, Eco. Mont., 3, 19-28, 2011.

Lugo, A. E., Castro, L. M., Vale, A., López, T. M., Prieto, E. H., Martinó, A. G., Rolón, A. R. P., Tossas, A. G., McFarlane, D. A., Miller, T., Rodríguez, A., Lundberg, J., Thomlinson, J., Colón, J., Schellekens, J. H., Ramos, O., and Helmer, E.: Puerto Rican Karst-A Vital Resource, United States Department of Agriculture Forest Service General Technical Report WO-65, 2001.

Maloszewski, P., Stichler, W., Zuber, A., and Rank, D.: Identifying the flow systems in a karstic-fissured-porous aquifer, the Schneealpe, Austria, by modelling of environmental ${ }^{18} \mathrm{O}$ and ${ }^{3} \mathrm{H}$ isotopes, J. Hydrol., 256, 48-59, https://doi.org/10.1016/S00221694(01)00526-1, 2002.

Marín, A. I., Andreo, B., and Mudarra, M.: Vulnerability Mapping and Protection Zoning of Karst Springs. Validation by Multitracer Tests, Sci. Total Environ., 532, 435-446, https://doi.org/10.1016/j.scitotenv.2015.05.029, 2015.

Markowska, M., Baker, A., Andersen, M. S., Jex, C. N., Cuthbert, M. O., Rau, G. C., Graham, P. W., Rutlidge, H., Mariethoz, G., Marjo, C. E., Treble, P. C., and Edwards, N.: Semi-Arid Zone Caves: Evaporation and Hydrological Controls on $\Delta^{18} \mathrm{O}$ Drip Water Composition and Implications for Speleothem Paleoclimate Reconstructions, Quaternary Sci. Rev., 131, 285-301, https://doi.org/10.1016/j.quascirev.2015.10.024, 2016.

Martini, E., Wollschläger, U., Kögler, S., Beherns, T., Dietrich, P., Reinstorf, F., Schmidt, K., Weiler, M., Werban, U., and Zacharias, S.: Spatial and Temporal Dynamics of Hillslope-Scale Soil Moisture Patterns: Characteristic States and Transition Mechanisms, Vadose Zone J., 14, 1-16, https://doi.org/10.2136/vzj2014.10.0150, 2015.

Mazzilli, N., Guinot, V., Jourde, H., Lecoq, N., Labat, D., Arfib, B., Baudement, C., Danquigny, C., Dal Soglio, L., and Bertin, D.: KarstMod: A Modelling Platform for Rainfall - Discharge Analysis and Modelling Dedicated to Karst Systems, Environ. Modell. Softw., 122, 103927 , https://doi.org/10.1016/j.envsoft.2017.03.015, 2019. 
Mudarra, M.: Importancia Relativa de La Zona No Saturada y Zona Saturada En El Funcionamiento Hidrogeológico de Los Acuíferos Carbonáticos, Caso de La Alta Cadena, Sierra de Enmedio y Área de Los Tajos (Provincia de Málaga), Malaga, University of Malaga, Spain, 2012.

Mudarra, M. and Andreo, B.: Relative Importance of the Saturated and the Unsaturated Zones in the Hydrogeological Functioning of Karst Aquifers: The Case of Alta Cadena (Southern Spain), J. Hydrol., 397, 263-280, https://doi.org/10.1016/j.jhydrol.2010.12.005, 2011.

Mudarra, M., Andreo, B., Marín, A. I., Vadillo, I., and Barberá, J. A.: Combined Use of Natural and Artificial Tracers to Determine the Hydrogeological Functioning of a Karst Aquifer: The Villanueva Del Rosario System (Andalusia, Southern Spain), Hydrogeol. J., 22, 1027-1039, https://doi.org/10.1007/s10040-0141117-1, 2014.

Mudarra, M., Hartmann, A., and Andreo, B.: Combining Experimental Methods and Modeling to Quantify the Complex Recharge Behavior of Karst Aquifers, Water Resour. Res., 55, 1384-1404, https://doi.org/10.1029/2017WR021819, 2019.

Nationalpark Berchtesgaden: Nationalparkplan, Karte 3: Bodentypen, Kartografie: Kilian, D., published by: Bayerisches Staatsministeriumfür Landesentwicklung und Umweltfragen, Munich (Germany), 2001.

Ollivier, C., Mazzilli, N., Olioso, A., Chalikakis, K., Carrière, S. D., Danquigny, C., and Emblanch, C.: Karst Recharge-Discharge Semi Distributed Model to Assess Spatial Variability of Flows, Sci. Total Environ., 703, 134368, https://doi.org/10.1016/j.scitotenv.2019.134368, 2019.

Osborne, R. A. L.: Cathedral Cave, Wellington Caves, New South Wales, Australia. A Multiphase, Non-Fluvial Cave, Earth Surf. Proc. Land., 32, 2075-2103, https://doi.org/10.1002/esp.1507, 2007.

Perrin, J., Jeannin, P. Y., and Zwahlen, F.: Epikarst Storage in a Karst Aquifer: A Conceptual Model Based on Isotopic Data, Milandre Test Site, Switzerland, J. Hydrol., 279, 106-124, https://doi.org/10.1016/S0022-1694(03)00171-9, 2003.

Peyre, Y.: Géologie D’Antequera et de Sa Région (Cordillères Bétiques, Espagne), University of Paris, Paris, 1974.

Quiñones, A.: Water Resources of the Lower Rio Grande de Arecibo Alluvial Valley, Puerto Rico, https://doi.org/10.3133/wri854160, 1986.

Rahman, M. and Rosolem, R.: Towards a simple representation of chalk hydrology in land surface modelling, Hydrol. Earth Syst. Sci., 21, 459-471, https://doi.org/10.5194/hess-21-4592017, 2017.

Ries, F., Lange, J., Schmidt, S., Puhlmann, H., and Sauter, M.: Recharge estimation and soil moisture dynamics in a Mediterranean, semi-arid karst region, Hydrol. Earth Syst. Sci., 19, 1439-1456, https://doi.org/10.5194/hess-19-1439-2015, 2015.

Rivera-Sostre, M. L.: Variación En La Dieta Del Sapo de La Caña (Chaunus [Bufo] Marinus) En La Reserva Natural Privada El Tallonal En Arecibo, Puerto Rico', MS thesis, University of Puerto Rico, Puerto Rico, 2008.

Rutlidge, H., Baker, A., Marjo, C. E., Andersen, M. S., Graham, P. W., Cuthbert, M. O., Rau, G. C., Roshan, H., Markowska, M., Mariethoz, G., and Jex, C. N.: Dripwater Organic Matter and Trace Element Geochemistry in a Semi-Arid Karst Environment: Implications for Speleothem
Paleoclimatology, Geochim. Cosmochim. Ac., 135, 217-230, https://doi.org/10.1016/j.gca.2014.03.036, 2014.

Sarrazin, F., Hartmann, A., Pianosi, F., Rosolem, R., and Wagener, T.: V2Karst V1.1: a parsimonious large-scale integrated vegetation-recharge model to simulate the impact of climate and land cover change in karst regions, Geosci. Model Dev., 11, 4933-4964, https://doi.org/10.5194/gmd-11-4933-2018, 2018.

Seiglie, G. A. and Moussa, M. T.: Late Oligocene-Pliocene Transgressive Regressive Cycles of Sedimentation in Northwestern Puerto Rico, in: Interregional Unconformities and Hydrocarbon Accumulation, edited by: Schlee, J. S., American Association of Petroleum Geologists Memoir, 36, 89-98, 1984.

Sprenger, M., Volkmann, T. H. M., Blume, T., and Weiler, M.: Estimating flow and transport parameters in the unsaturated zone with pore water stable isotopes, Hydrol. Earth Syst. Sci., 19, 2617-2635, https://doi.org/10.5194/hess-19-2617-2015, 2015.

Trček, B.: How Can the Epikarst Zone Influence the Karst Aquifer Hydraulic Behaviour?, Environ. Geol., 51, 761-765, https://doi.org/10.1007/s00254-006-0387-x, 2007.

Troester, J. W.: Geochemistry and Hydrogeologic Framework of the Saline-Freshwater Interface and the Calculation of the Net Recharge in the Dorado Area, North-Central Puerto Rico, Water Resources Investigations Report 98-4030, San Juan, PR, US Geological Survey, 1999.

Viera M., C. A., Abelleira Martinez, O. J., and Lugo, A. E.: Estructura y química del suelo en un bosque de Castilla elastica en el carso del norte de Puerto Rico: resultados de una calicata, Acta Cient., 22, 29-35, 2008.

Vörösmarty, C. J., McIntyre, P. B., Gessner, M. O., Dudgeon, D., Prusevich, A., Green, P., Glidden, S., Bunn, S. E., Sullivan, C. A., Liermann, C. R., and Davies, P. M.: Global Threats to Human Water Security and River Biodiversity, Nature, 467, 555561, https://doi.org/10.1038/nature09440, 2010.

Wada, Y., van Beek, L. P. H., van Kempen, C. M., Reckman, J. W. T. M., Vasak, S., and Bierkens, M. F. P.: Global Depletion of Groundwater Resources: GLOBAL GROUNDWATER DEPLETION, Geophys. Res. Lett., 37, L20402, https://doi.org/10.1029/2010GL044571, 2010.

Wheater, H. S., Peach, D., and Binley, A.: Characterising groundwater-dominated lowland catchments: the UK Lowland Catchment Research Programme (LOCAR), Hydrol. Earth Syst. Sci., 11, 108-124, https://doi.org/10.5194/hess-11-108-2007, 2007.

Williams, P. W.: The Role of the Subcutaneous Zone in Karst Hydrology, J. Hydrol., 61, 45-67, https://doi.org/10.1016/00221694(83)90234-2, 1983.

Zhang, Z., Chen, X., Chen, X., and Shi, P.: Quantifying Time Lag of Epikarst-Spring Hydrograph Response to Rainfall Using Correlation and Spectral Analyses', Hydrogeol. J., 21, 1619-1631, https://doi.org/10.1007/s10040-013-1041-9, 2013.

Zhou, Q., Sun, Z., Liu, X., Wei, X., Peng, Z., Yue, C., and Luo, Y.: Temporal Soil Moisture Variations in Different Vegetation Cover Types in Karst Areas of Southwest China: A Plot Scale Case Study, Water, 11, 1423, https://doi.org/10.3390/w11071423, 2019. 